\title{
DETOXIFICATION OF PESTICIDES POLLUTED SOIL BY ADSORBTION ON ACTIVATED CARBONS
}

\author{
V.M. Mukhina*, Yu. Ya. Spiridonov ${ }^{\mathrm{b}}$, T.G. Lupascu ${ }^{\mathrm{c}}$ \\ ${ }^{a}$ Electrostal scientific-manufacturing union "Неорганика"(Neorganica), Electrostal, Moscow region, Russia \\ ${ }^{b}$ Research Institute of Phytopathology of the Russian Academy of Agricultural Sciences, Moscow region, Russia \\ ${ }^{c}$ Institute of Chemistry of the Academy of Sciences of Moldova, Chisinau, Moldova \\ *Address: Electrostal 144001, 4 Karl Marx str., Moscow region, Russia; email:neorg.el@mail.ru
}

\begin{abstract}
The paper emphasizes a very severe social-ecological problem, related to the contamination of soils by pesticides and fodder micotoxins. The authors suggest the utilization of a carbon adsorption based method of purification of soils contaminated with traces of pesticides. It is demonstrated that this method of soil rehabilitation leads to an $80 \%$ crop increase, allowing the production of environmentally clean plant products. The utilization of special activated carbons "Ptitsesorb" leads to a $30-40 \%$ decrease of necessary combined fodder in chickens breeding.
\end{abstract}

Keywords: pesticides, soil, activated carbon, detoxification.

One of the major threats to the biosphere is the decrease of soil fertility and total exhaust of agricultural fields as a result of technogenic activity. The soils of agricultural areas constitute only $6 \%$ of the total land surface, and almost $40 \%$ of it belongs to Russia. Considering the fact that over 10 billion people will be living on Earth by the end of the $\mathrm{XXI}^{\text {st }}$ century, primordial attention should be focused on the protection and rehabilitation of soils.

The large scale utilization of various chemicals, including pesticides, in local and world agricultural practice lead to the aggravation of medical-environmental matters caused by the pollution of plant cultivation and zootechny products, and of the entire biosphere, in general. To date, the number of poisonous chemicals used in various countries is close to thousand; approximately three hundred of them are widely used. In these conditions, it is absolutely necessary to possess methods and sources which would allow the elimination of the harmful action of pesticides on cultured and wild plants and get environmentally clean production of phytotechny and zootechny [1].

Considering the solving of environmental issues of the agro-industrial complex, activated carbons (AC) are characterized by several advantages, such as selectivity of sorption of organic toxicants, universality of sorption properties, high adsorptive capacity, hydrophobicity, convenient preparation form (granules, powder) and low cost (1,5$2,0 \mathrm{USD} / \mathrm{kg})$.

Table 1

Efficiency of recovery of soil fertility, polluted with herbicides traces, using modified $\mathrm{AC}$ in doses of $100 \mathrm{~kg} / \mathrm{ha}$

\begin{tabular}{|c|c|c|}
\hline Trace amounts of herbicides in soil & Culture & $\begin{array}{c}\text { Index of preserved crop of test-cultures, } \\
\text { \% of polluted control }\end{array}$ \\
\hline \hline \multirow{3}{*}{ Chlorsulphuron, $0,2 \mathrm{~g} / \mathrm{ha}$} & Cucumber & $16-20$ \\
\cline { 2 - 3 } & Beet & $58-63$ \\
\cline { 2 - 3 } & Radish & $23-28$ \\
\hline \multirow{2}{*}{ Terbacil, $1,4 \mathrm{~kg} / \mathrm{ha}$} & Cucumber & $23-27$ \\
\cline { 2 - 3 } & Beet & $64-69$ \\
\cline { 2 - 3 } & Radish & $30-39$ \\
\hline Picloram, $2 \mathrm{~g} / \mathrm{ha}$ & Cucumber & $22-24$ \\
\hline Simazine, $50 \mathrm{~g} / \mathrm{ha}$ & Tomato & $22-26$ \\
\hline \multirow{2}{*}{ Chlorsulphuron, $0,4 \mathrm{~g} / \mathrm{ha}$} & Tomato & $98-100$ \\
\cline { 2 - 3 } & Beet & $98-99$ \\
\cline { 2 - 3 } & Radish & $98-100$ \\
\hline
\end{tabular}

Regardless of the actuality of this issue, carbonic adsorbents haven't been produced for soil detoxification until recently. Therefore, the authors presented a theoretical argumentation of the requirements for the porous structure and preparative forms of AC used particularly for agro-sorption, and also the technologies of its introduction into soil.

It is disclosed that agro-sorbents must possess a micropores volume of not less than $0,2-0,3 \mathrm{~cm}^{3} / \mathrm{g}$ and a significant development of thin pores $(0,4-0,6 \mathrm{~nm})$, allowing a strong retention of pesticides molecules, and also the products of 
its destruction, and the transporting porosity must be well developed in order to provide a good adsorption kinetics of these compounds [2].

Experimental results obtained in a synthetic environment laboratory using various types and concentrations (corresponding to real trace amounts) of herbicides in soils, are presented in table 1. According to these data, activated carbons are indeed a universal tool for the recovery of fertility of polluted soil, regardless of the type and trace amount of herbicide, increasing crop yield by $20-100 \%$.

Another significant result of AC adsorption based soil detoxification consists in collecting environmentally clean production of plants and vegetables. The data presented in tables 2 and 3 were obtained during comparative experimental studies on agricultural crops cultured according to the usual technology and using carbonic adsorbents. According to these data, the utilization of activated carbons on polluted areas in doses up to $100 \mathrm{~kg} / \mathrm{ha}$ (in the case of cultured barley, up to $200 \mathrm{~kg} / \mathrm{ha}$ ) leads to a sharp decrease, and in several cases - to a total elimination, of herbicides accumulation in the products of plants and vegetable growing.

Table 2

Accumulation of herbicides by agricultural cultures

\begin{tabular}{|c|c|c|c|}
\hline Dose of herbicide, $\mathrm{kg} / \mathrm{ha}$ & Dose of AC, $\mathrm{kg} / \mathrm{ha}$ & Test-culture & $\begin{array}{c}\text { Amount of herbicide in the } \\
\mathrm{crop}, \mu \mathrm{g} / \mathrm{kg}\end{array}$ \\
\hline Treflan -1 & - & Tomato & 28 \\
\hline Treflan -1 & 100 & Tomato & 0,6 \\
\hline Treflan -1 & - & Carrot & 95 \\
\hline Treflan -1 & 100 & Carrot & Not found \\
\hline $2,4-\mathrm{D}-5$ & - & Barley & 220 \\
\hline $2,4-\mathrm{D}-5$ & 200 & Barley & Not found \\
\hline $2,4-\mathrm{D}-10$ & - & Barley & 670 \\
\hline $2,4-\mathrm{D}-10$ & 200 & Barley & Not found \\
\hline \multicolumn{2}{|c|}{ 2,4-D - 2,4-Dichlorphenoxy acetic acid } \\
\hline
\end{tabular}

Table 3

Accumulation of atrazine by corn

\begin{tabular}{|c|c|c|c|c|c|c|}
\hline $\begin{array}{c}\text { Dose of AC, } \\
\mathrm{kg} / \mathrm{ha}\end{array}$ & \multicolumn{2}{|c|}{$\begin{array}{c}\text { In the green mass per ensile, } \mu \mathrm{g} / \mathrm{kg}, \\
\text { using the atrazine dose, } \mathrm{kg} / \mathrm{ha}\end{array}$} & \multicolumn{3}{c|}{$\begin{array}{c}\text { In the grains, } \mu \mathrm{g} / \mathrm{kg}, \\
\text { using the atrazine dose, } \mathrm{kg} / \mathrm{ha}\end{array}$} \\
\cline { 2 - 7 } & $\mathbf{8}$ & $\mathbf{1 6}$ & $\mathbf{3 2}$ & $\mathbf{8}$ & $\mathbf{1 6}$ & 32 \\
\hline 0 & 2 & 5 & 13 & 7 & 11 & 29 \\
\hline 50 & Not found & Not found & 1 & Not found & 1 & 2 \\
\hline 100 & Not found & Not found & Not found & Not found & Not found & Not found \\
\hline
\end{tabular}

On the basis of these data, in 2000 the State Commission of the Russian Federation registered the activated carbons "Agrosorb-1", "Agrosorb-1G" and "Jiznedar", and allowed their practical utilization as soil melioration agents in largesized Russian agricultural enterprises, as well as in individual households for recovery of soil fertility and acquirement of environmentally clean plant production (state registration № 13-9089-0332-1, 13-9090(9962-9966)-0132-1).

Summarizing the described above work, we should mention the significant economical and environmentaleconomical effects due to the recovery of fertility of pesticides polluted soil, evidenced by the increase of crop yield of respective cultures, by the return of polluted areas in the sowing cycle and acquirement of dietetic products of plants and vegetables growing. According to the data of the Research Institute of Phytopathology of the Russian Academy of Agricultural Sciences, the potential environmental-economical effect of soil detoxification rises up to 300 USD per ha and could constitute around 20 bill. USD/year (considering the prices of 1999) in the Moscow region, alone. The importance of this is even greater, as all available data indicate that pesticide pollution in doses which inhibit cultured plants growth is evidenced on 50 mill. ha of fields. In particular, in the Krasnodar region, characterized by a very intense agriculture, the area of agricultural fields where pesticide pollution exceeds admissible limits constitutes over 240 thousands ha. In the case of intense implementation of AC in agricultural practices during the following years, the amount of $\mathrm{AC}$ required by the Krasnodar region alone will constitute around 25-30 thousands tones/year [1].

The technogenic and demographic loads increasingly influence environmental pollution. Naturally, the production of environmentally clean food, including the products of zootechny, swine-breeding, aviculture, encounters increasing difficulties. The fodder necessary for animal breeding is polluted by xenobiotics in a controlled manner (for example 
during pesticide treatment of plants), but also accidently (for example in the case of micotoxins affection of grains during storage and processing). It has to be mentioned that accidental, uncontrolled pollution of fodder is continuously increasing, and it is often detected only after the perishing of animals and birds.

In order to neutralize the harmful influence of polluted fodder on the efficiency of animal breeding and aviculture, various mineral and organic additives are widely used (such as "Micosorb", "Biosorb" etc.), which always solve only one, very specific task. However, globalisation sets new requirements for such an important branch, as combined fodder production, therefore a wide utilization of special activated carbons is imperative for animal breeding and aviculture [3].

Lately, issues related to chicken breeding gained increasing significance, considered as one of the most dynamic branch of meat production. In most cases, micotoxins and other xenobiotics are constantly discovered in fodder materials for agricultural animals and birds, and even small concentrations of these substances significantly affect specialized aviary enterprises.

The efficiency of AC "Ptitsesorb", used as a detoxifying agent at chicken aviaries in the case of utilization of combined fodder contaminated by various micotoxins was confirmed in the Institute of Aviculture (in Sergyev Posad)in 2005 (Tab. 4) by its addition in a dose of $0,5 \%$ mass.

Table 4

Efficiency of "Ptitsesorb" AC in the case of utilization of combined fodders, contaminated by several micotoxins (DON - 3,2 $\mu \mathrm{g} / \mathrm{kg}, \mathrm{T}-2-121 \mu \mathrm{g} / \mathrm{kg}, \mathrm{B} 1-9,5 \mu \mathrm{g} / \mathrm{kg}$ )

\begin{tabular}{|c|c|c|c|}
\hline Groups & $\begin{array}{c}\text { Safety } \\
\text { of birds number, } \%\end{array}$ & $\begin{array}{c}\text { Combined fodder consumption } \\
\text { for 1 kg of mass augmentation, } \\
\mathrm{kg}\end{array}$ & $\begin{array}{c}\text { Decrease of production } \\
\text { consumption, } \%\end{array}$ \\
\hline BR with dose of toxins $133,7 \mu \mathrm{g} / \mathrm{kg}$ & 86 & 2,06 & - \\
\hline $\begin{array}{c}\text { BR with dose of toxins } \\
133 \mu \mathrm{g} / \mathrm{kg}+0,5 \% \mathrm{AC}\end{array}$ & $90-93$ & $1,91-1,93$ & $30-40$ \\
\hline
\end{tabular}

Note: $\mathrm{BR}$ - basic ration.

A significant increase in birds safety and mean daily mass augmentation of chickens was observed when $0,5 \%$ of "Ptitsesorb" AC was included into trichotecene micotoxins infected fodder ration; the birds commenced a better usage of the ration nutrients, which caused enhancement of most production indices of chicken breeding, as compared to chicken which consumed analogical fodder with no added AC.

Thus, as presented in table 4, the AC "Ptitsesorb" produced by the ESMU "Neorganica", included into birds ratio in doses of $0,5-1,0 \%$, determined a $30-40 \%$ decrease of production costs, caused by the negative influence of fodder micotoxins.

Obtained data prove that fodder producing companies ought to use AC on large scale not only to increase economical indices of a given branch plant growing, zootechny, aviculture, hatchery, but also to confer new quality characteristics to the food consumed by people, in terms of its environmental cleanness, thus enhancing people's life quality.

\section{References}

[1]. Mukhin V.M., Spiridonov Yu. Ia. Sorption based detoxification of soils contaminated with pesticides, Issues of environmental security of the agro-industrial complex (in Russian), published by the Russian Academy of Agricultural Sciences: Minselihozprod RF, 1999, 4, pp. 30-38.

[2]. Mukhin V.M., Tarasov A.V., Klushin V. N. Russian activated carbons (in Russian). Metallurgy: Moscow, 2000, $352 \mathrm{p}$.

[3]. Mukhin V.M., Guliushin S. Preparation for the profilaxy of fodder derived intoxications. Combined fodders (in Russian), 2007, 4, pp. 72-73. 